\title{
Comparison of Helicobacter spp. genetic sequences in wild and captive seals, and gulls
}

\author{
Andrew P. A. Oxley ${ }^{1,3, *}$, David B. McKay ${ }^{2}$ \\ ${ }^{1}$ National Marine Science Centre, Coffs Harbour, New South Wales 2450, Australia \\ ${ }^{2}$ The Faculty of Science, University of the Sunshine Coast, Maroochydore D.C., Queensland 4558, Australia \\ ${ }^{3}$ Present address: Department of Primary Industries, RMB 1145 Chiltern Valley Road, Rutherglen, Victoria 3685, Australia
}

\begin{abstract}
Helicobacter species are widely distributed in the gastrointestinal system of humans and many animal taxa. Investigations of natural infections are essential to elucidating their role within the host. The feces of fur seals Arctocephalus pusillus doriferus and sea lions Neophoca cinerea from 3 separate captive populations, as well as a wild colony from Kangaroo Island, Australia, were examined for the occurrence of Helicobacter spp. The feces from several wild silver gulls Larus novahollandiae were also investigated. As detected by PCR, 18 of 21 samples from captive and 12 of 16 samples from wild seals were positive for Helicobacter spp. Three species were identified in these animals. Whilst one possibly novel type was identified from wild fur seals, the majority of wild and captive individuals had the same species. This species also occurred in more than 1 seal type and in silver gulls, and shared a 98.1 to $100 \%$ identity to other Helicobacter spp. from harp seals and sea otters. A similar sequence type to species identified from cetaceans was also detected in several captive seals. This study reports for the first time the presence of Helicobacter spp. in wild and captive seals and demonstrates the diversity and broad-host range of these organisms in the marine host.
\end{abstract}

KEY WORDS: Helicobacter $\cdot$ Natural reservoir $\cdot$ Wild and captive seals $\cdot$ Sea birds

\section{INTRODUCTION}

The genus Helicobacter comprises 24 formally recognized species and occurs within humans and a broad range of animal taxa including rodents, cats, dogs, monkeys, birds, pigs and cattle (for a review see Solnick \& Schauer 2001, Fox 2002). Species different to those previously characterized from terrestrial mammals have also been reported from the stomach and feces of marine mammals including dolphins, whales, harp seals and sea otters (Harper et al. 2002, 2003a,b). Whilst many Helicobacter spp. (including $H$. cetorum from dolphins and whales) have been associated with gastrointestinal diseases such as gastroenteritis, peptic ulceration and gastric cancer (Fox \& Lee 1997), they may also occur within the asymptomatic host (Mazzucchelli et al. 1994, Simmons et al. 2000). The widespread nature of Helicobacter spp. in animal hosts (Gebhart et al. 1989, Neiger et al. 1998, Fernandez et al. 2002) suggests these organisms form part of the host's indigenous gut flora (Simmons et al. 2000). The emergence of disease may therefore be, in part, due to host dependent factors (Cover 1997) or to the infection of the host with species that do not usually colonize its gut (Solnick \& Schauer 2001).

Within humans and terrestrial animals, the ability of Helicobacter spp. to spread between hosts has been reported to occur via a fecal-oral or oral-oral mode of transmission (Brown 2000). In some instances, this may also involve an intermediate host (such as birds) which may act as a reservoir for its dispersal (Walderström et al. 2003). Although it has been suggested that similar processes may exist for marine mammals (Harper et al. 2003a), the mode/s of transmission in these animals is unknown.

With the ability of many Helicobacter spp. to infect more than 1 host type (Fox 2002), there is increasing concern for their potential as agents of disease in the 
husbandry of many animals, including seals (Goldman et al. 2002, Al-Soud et al. 2003). Recently, 2 novel Helicobacter spp. were isolated and characterized from the gut of a stranded wild harp seal Phoca groenlandica exhibiting marked gastritis from the coastline of North America (Harper et al. 2003b). One other individual tested positive for Helicobacter spp. using PCR, out of a total of only 4 animals investigated. Moreover, other organisms that may also cause gastritis, such as helminth parasites and Cryptosporidium spp. (Lauckner 1985, Oros et al. 1998), were also observed in the gut of these animals. Thus, given the detection of Helicobacter spp. in a small number of wild animals only and, more importantly, its tentative attribution in the etiopathogenesis of disease, the prevalence and role of these organisms in wild seals is unclear. Furthermore, its prevalence in captive seals has not been previously investigated.

In this study we report the presence of Helicobacter spp. in the feces of Australian (AUS) and New Zealand (NZ) fur seals Arctocephalus pusillus doriferus and A. forsteri, Australian and Californian sea lions Neophoca cinerea and Zalophus californianus, and sea birds (silver gulls Larus novahollandiae). Three separate captive populations as well as 1 wild seal colony from Kangaroo Island, Australia were examined using 16S rRNA PCR and sequence analyses. Although 1 individual ('Duran') maintained a clinical history of gastritis, all captive animals were asymptomatic at the time of sampling.

\section{MATERIALS AND METHODS}

Sampling. Fecal samples were collected from the enclosures of 21 captive seals (10 Australian sea lions, 2 Australian fur seals, 1 Californian sea lion, and 8 other unspecified fur seals) from 3 independent populations, UnderWater World (UWW), Sea World (SW) and the Aquarium of Western Australia (AQWA). All samples were collected from animals housed within the same enclosures that were cleaned prior to and throughout the sampling period. Also, apart from SW, no other marine mammal taxa (such as dolphins or whales) were housed at either facility at the time of sampling.

Feces were also collected from 16 wild seals (13 NZ fur seals and 3 AUS fur seals) and a number of wild silver gulls from Kangaroo Island, Australia.

A $20 \mathrm{~g}$ fecal sample was collected from each individual, placed into a sterile collection vial containing $40 \mathrm{ml}$ of sterile phosphate buffered saline (PBS) supplemented with $20 \%$ glycerol, mixed and placed immediately on ice. Where samples could not be analysed within $1 \mathrm{~h}$ of collection, they were stored at $-20^{\circ} \mathrm{C}$ for no more than $14 \mathrm{~d}$. Experiments showed that the storage of the sample at $-20^{\circ} \mathrm{C}$ in a PBS and $20 \%$ glycerol medium was the most appropriate for the recovery of template DNA and its amplification for this period (data not shown). For samples collected from wild silver gulls, a total of approximately $20 \mathrm{~g}$ was also collected. However, each of these samples contained material from numerous individuals.

Total DNA extractions. Prior to DNA extraction, samples from captive and wild seals and silver gulls (if frozen) were thawed overnight at $4^{\circ} \mathrm{C}$. Each sample was homogenized for 1 to $5 \mathrm{~min}$ and a $200 \mu \mathrm{l}$ aliquot (or approximately $200 \mathrm{mg}$ ) was removed and placed into a sterile $2 \mathrm{ml}$ microcentrifuge tube. The total DNA was extracted from fecal samples using a QIAamp DNA Stool Mini Kit (Qjagen) and re-eluted in $200 \mu \mathrm{l}$ of elution buffer. As a control for the extraction process, $10 \mu \mathrm{l}$ of a $10^{8} \mathrm{CFU} \mathrm{mm^{-1 }}$ culture of Helicobacter pylori strain 26695 (School of Microbiology and Immunology, University of New South Wales, Australia) was added to a $200 \mu \mathrm{l}$ aliquot of the fecal homogenate and processed in conjunction with all other samples.

PCR reaction conditions. To establish if Helicobacter spp. were present within the feces of captive and wild seals and of silver gulls, the following genus-specific primers were used to produce 16S rRNA amplicons of approximately $400 \mathrm{bp}$ in length: 5'-TATGACGGGTATCCGGC-3' (H276 forward) and 5'ATTCCACCTACCTCTCCCA-3' (H676 reverse) (Germani et al. 1997). Total volumes of $30 \mu$ l were used in all PCR reactions and were performed in an Eppendorf Mastercycler ${ }^{\circledR}$ gradient (Eppendorf). Reaction mixtures contained 25 pmol of each primer, $1 \times$ PCR reaction buffer (67 mM Tris- $\mathrm{HCl}[\mathrm{pH} 8.8], 16.6 \mathrm{mM}\left[\mathrm{NH}_{4}\right]_{2} \mathrm{SO}_{4}$, $0.45 \%$ Triton X-100, $0.2 \mathrm{mg} \mathrm{ml}^{-1}$ gelatin), $2.5 \mathrm{mM} \mathrm{MgCl}_{2}$, $170 \mu \mathrm{M}$ of deoxyribonucleoside triphosphate, $1.0 \mathrm{U}$ of Taq polymerase (Biotech International) and $2 \mu$ of DNA extract. All reactions were heated at $94^{\circ} \mathrm{C}$ for 2 min and then subjected to 30 cycles consisting of: denaturation at $94^{\circ} \mathrm{C}$ for $30 \mathrm{~s}$, annealing at $66^{\circ} \mathrm{C}$ for $30 \mathrm{~s}$ and extension at $72^{\circ} \mathrm{C}$ for $30 \mathrm{~s}$. A $5 \mu \mathrm{l}$ aliquot from each of the PCR reactions was separated by electrophoresis in a $1 \%$ agarose gel, stained with ethidium bromide, visualized under UV light and the image recorded using GeneSnap (Version 4.00.00) (Syngene).

PCR controls. To verify the results of the PCR, several controls were included with each series of reactions. These included 2 positive and 2 negative controls. One positive control (+VE) was used to detect PCR inhibition and contained $1 \mu \mathrm{l}$ of the fecal DNA extract and $1 \mu \mathrm{l}$ of genomic DNA obtained from Helicobacter pylori. The other positive control (HP) was used to verify the success of the PCR reaction and contained $2 \mu \mathrm{l}$ of $H$. pylori genomic DNA. The negative controls were used to detect the presence of false amplification products and contained either $2 \mu \mathrm{l}$ of Escherichia coli genomic DNA (EC) or $2 \mu \mathrm{l}$ of water (W). 
Cloning, plasmid isolation and sequencing. Amplicons were cloned using the pGEM $^{\circledR}$-T Easy Vector System (Promega). In accordance with the manufacturer's instructions, $3 \mu \mathrm{l}$ of the PCR product was ligated with $50 \mathrm{ng}$ of vector at room temperature for $1 \mathrm{~h}$ and transformed with High Efficiency JM109 competent cells (Promega). Clones were selected using ampicillin plates containing IPTG and X-Gal and screened for inserts using the CloneChecker' System (Invitrogen). Plasmid DNA was isolated from Escherichia coli JM109 cells using the Wizard ${ }^{\circledR}$ Plus SV Minipreps DNA Purification System (Promega). DNA was submitted to the Australian Genome Research Facility (AGRF) and sequenced with ABI prism BigDye Terminator cycle sequencing kit (Applied Biosystems).

Sequence analysis. Sequences were entered into BioEdit sequence alignment editor for Windows 95/98/NT (Version 5.0.9) (Hall 1999) and aligned using ClustalW (Version 1.4) (Thompson et al. 1994). To determine the variation (if any) between sequences obtained from wild and captive seals and silver gulls, sequences were aligned alongside other Helicobacter spp. sequences retrieved from GenBank. According to present guidelines, a difference in nucleotide sequence of approximately $3 \%$ or greater between any 2 rDNAs was used to distinguish a separate species (Stackebrandt \& Goebel 1994). Tree diagrams representing these alignments were constructed with the Molecular Evolutionary Genetics Analysis program (MEGA) (Version 2.1) (Kumar et al. 2001) using the neighbor-joining method.

Nucleotide sequence accession numbers. The $16 \mathrm{~S}$ rRNA sequences obtained from this study were submitted to the GenBank database, and the accession numbers are given in Fig. 1.

\section{RESULTS}

\section{PCR detection of Helicobacter spp.}

The detection of Helicobacter by PCR analysis of total DNA extracted from fecal material collected from seals from 3 independent captive populations, UnderWater World (UWW), Sea World (SW) and the Aquarium of Western Australia (AQWA), as well as wild seals and silver gulls from Kangaroo Island, Australia is presented in Table 1. As established by the presence of amplicons of the expected size of approximately $400 \mathrm{bp}$ (data not shown), samples from 18 of 21 captive and 12 of 16 wild seals tested positive for Helicobacter. In addition, 1 of the 2 samples obtained from wild silver gulls also tested positive for the presence of Helicobacter spp.

\section{Analysis of sequences}

To identify any differences between sequences obtained from the feces of captive and wild seals and silver gulls, an alignment was constructed from sequences from all 3 captive populations and the wild sampling period. Moreover, to identify if any of these sequences grouped with previously identified Helicobacter spp., sequences obtained from the GenBank database for other members of this genus were also included in the alignment. A tree diagram representing this alignment is presented in Fig. 1.

All sequences obtained from captive and wild seals and silver gulls clustered with members of the genus Helicobacter. At least 3 distinct groups of sequences differing by 10 to $20 \mathrm{bp}$ (94.9 to $97.5 \%$ identity) were observed. Within each of these groups of sequences, differences of no more than 8 bp (98.1\% identity) were also observed. Based on a $3 \%$ difference in nucleotide sequence representing a separate species (Stackebrandt \& Goebel 1994), these 3 groups may thus represent 3 distinct Helicobacter species to these animals.

Group 1 consisted of sequences from captive seals only (AQWA seals 2, 4 and 7, and UWW seal 3). Interestingly, with a difference in nucleotide sequence of 6 to $8 \mathrm{bp}$ (98 to $98.6 \%$ identity), this group also clustered with previously identified Helicobacter spp. from captive dolphins and whales (namely, H. cetorum).

Group 2 comprised sequences from only wild seals (NZ fur seals 10 and 13). However, no other previously identified Helicobacter spp. appeared to cluster with this group of sequences; thus, this may represent a novel species.

Group 3 consisted of the majority of the sequences and included those obtained from both captive and wild seals and silver gulls (Captive seals: SW 2, 3 and 4, UWW 1, 2, 4, 5, and 6, and AQWA seals 1,6 and 8; Wild seals: AUS fur seals 1, 2 and 3, NZ fur seals 1, 2, 4, 6, 7, 11 and 12, and silver gulls 1). Whilst these sequences clustered with a Helicobacter spp. previously identified from dogs (namely, $H$. canis), like Group 1, these sequences also clustered with Helicobacter spp. from other marine mammals, including harp seals (Helicobacter sp. 'MIT 01-5529A'), sea lions (Helicobacter sp. 'MIT 02$5519 C^{\prime}$ ') and sea otters (Helicobacter sp. 'MIT 01$\left.5924^{\prime}\right)$.

Several sequences obtained from captive seals (SW seal 1 and AQWA seals 3 and 5) did not appear to belong to the 3 main sequence groups. However, an examination of the mean differences in nucleotide sequence revealed that with an identity of approximately $98.1 \%$, they most likely cluster with sequences from Group 3. 


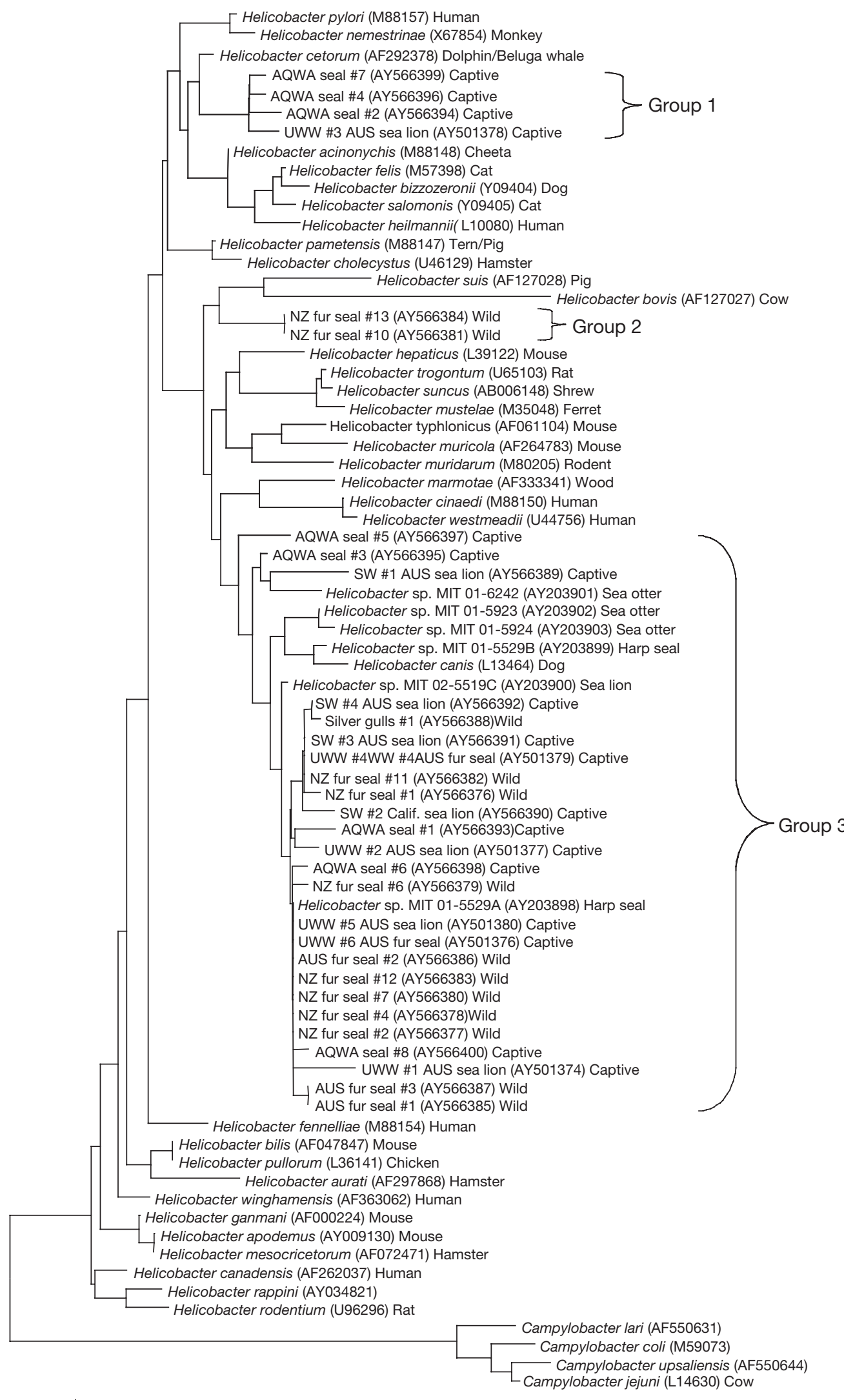

$\%$ Difference
Fig. 1. Neighbor-joining tree demonstrating the $16 \mathrm{~S}$ rRNA sequence identity between members of the genus Helicobacter and other Helicobacter spp. from the feces of wild Australian (AUS) and New Zealand (NZ) fur seals and silver gulls Larus novaehollandiae from Kangaroo Island, Australia, and captive seals (sea lions and fur seals) from 3 separate locations: UnderWater World (UWW), Sea World (SW) and the Aquarium of Western Australia (AQWA). The scale bar represents a $4 \%$ difference in nucleotide sequence. GenBank accession numbers are given in parentheses 
Table 1. PCR results of total DNA extracted from the feces of wild Australian (AUS) and New Zealand (NZ) fur seals, of silver gulls Larus novaehollandiae from Kangaroo Island, Australia, and of captive seals (sea lions and fur seals) from 3 separate locations: UnderWater World (UWW), Sea World (SW) and the Aquarium of Western Australia (AQWA). Samples were amplified with Helicobacter genus-specific primers targeting a $400 \mathrm{bp}$ region of the 16S rRNA operon. Animal identification (ID) numbers correspond to sequence data produced from the amplicons

\begin{tabular}{|c|c|c|c|c|}
\hline Location & $\begin{array}{c}\text { Habitat } \\
\text { setting }\end{array}$ & $\begin{array}{l}\text { Animal } \\
\text { type }\end{array}$ & $\begin{array}{l}\text { Animal ID } \\
\text { number }\end{array}$ & $\begin{array}{l}\text { PCR } \\
\text { result }\end{array}$ \\
\hline \multirow[t]{8}{*}{ UWW } & \multirow[t]{8}{*}{ Captive } & AUS & 1 & + \\
\hline & & sea lion & 2 & + \\
\hline & & & 3 & + \\
\hline & & & 5 & + \\
\hline & & & 7 & - \\
\hline & & & 8 & - \\
\hline & & AUS & 4 & + \\
\hline & & fur seal & 6 & + \\
\hline \multirow[t]{6}{*}{ SW } & \multirow[t]{6}{*}{ Captive } & AUS & 1 & + \\
\hline & & sea lion & 3 & + \\
\hline & & & 4 & + \\
\hline & & & 5 & - \\
\hline & & Californian & & \\
\hline & & sea lion & 2 & + \\
\hline \multirow[t]{8}{*}{ AQWA } & \multirow[t]{8}{*}{ Captive } & Unspecified & 1 & + \\
\hline & & fur seal & 2 & + \\
\hline & & & 3 & + \\
\hline & & & 4 & + \\
\hline & & & 5 & + \\
\hline & & & 6 & + \\
\hline & & & 7 & + \\
\hline & & & 8 & + \\
\hline \multirow{18}{*}{$\begin{array}{l}\text { Kangaroo } \\
\text { Island }\end{array}$} & \multirow[t]{18}{*}{ Wild } & NZ & 1 & + \\
\hline & & fur seal & 2 & + \\
\hline & & & 3 & - \\
\hline & & & 4 & + \\
\hline & & & 5 & - \\
\hline & & & 6 & + \\
\hline & & & 7 & + \\
\hline & & & 8 & - \\
\hline & & & 9 & - \\
\hline & & & 10 & + \\
\hline & & & 11 & + \\
\hline & & & 12 & + \\
\hline & & & 13 & + \\
\hline & & AUS & 1 & + \\
\hline & & fur seal & 2 & + \\
\hline & & & 3 & + \\
\hline & & Silver & 1 & + \\
\hline & & gulls & 2 & - \\
\hline
\end{tabular}

\section{DISCUSSION}

In examining 3 captive populations as well as a wild colony from Kangaroo Island, Australia, Helicobacter spp. were detected in the feces of the majority of both wild and captive seals (18 of 21 captive and 12 of 16 wild seals). Moreover, on the basis of $16 \mathrm{~S}$ rRNA sequences, at least one of the 3 Helicobacter sequence types detected was present in both wild and captive animals. A high incidence of Helicobacter spp. has been previously reported for both humans and a large number of animal taxa and whilst their occurrence may often be associated with disease (Fox \& Lee 1997, Solnick \& Schauer 2001), they may also occur within the asymptomatic host. For example, $H$. cinaedi was found in healthy hamsters and rhesus monkeys (Gebhart et al. 1989, Fernandez et al. 2002), H. heilmanii in cats (Neiger et al. 1998, Norris et al. 1999) and H. mesocricetorum in hamsters (Simmons et al. 2000). The occurrence of such species may thus reflect a commensal rather than a strictly pathogenic relationship with the host (Solnick \& Schauer 2001). Therefore, whilst the captive environment may present a unique habitat for outbreaks of potentially pathogenic organisms (Sweeney 1974, Dunn et al. 1984, Lauckner 1985, Fowler 1996, Higgins 2000), the high incidence and occurrence of similar Helicobacter spp. in both wild and asymptomatic captive seals may reflect organisms indigenous to this host. Nevertheless, with Helicobacter spp. recently detected in stranded wild harp seals with features of gastritis (Harper et al. 2003b) and, more importantly, in view of the fact that clinical signs of disease may be absent despite pathological changes (Dooley et al. 1989, Solnick \& Schauer 2001), others studies may be required to examine the role of the host in these infections.

Interestingly, sequences obtained from a large number of wild and captive AUS and NZ fur seals and captive AUS sea lions in this study clustered together and shared a 98.1 to $100 \%$ identity with other Helicobacter spp. obtained from harp seals (Helicobacter sp. MIT 01-5529A), sea lions (Helicobacter sp. MIT 02-5519C) and sea otters (Helicobacter sp. MIT 01-5923). Moreover, these sequences also clustered with a Helicobacter spp. previously characterized from dogs (namely H. canis) (Stanley et al. 1993). As hypothesized by Harper et al. (2003b), given the close evolutionary relationship of dogs and pinnipeds (Lento et al. 1995) and that other pathogenic organisms are common to both animal types (Smith et al. 1977, Lauckner 1985, Birnbaum et al. 1998, Forbes 2000), it is not surprising that they may also share similar Helicobacter species. Indeed, with most host-parasite associations (including Helicobacter) believed to reflect the 'coevolution' of the host and its microbial flora (Thomas et al. 1996, Covacci et al. 1999), the similarity in sequence types between seals in this study with those from geographically separate locations in the Northern hemisphere (Harper et al. 2003b) may highlight this phylogenetic history.

One group of sequences, representing a single sequence type was also obtained from several wild NZ 
fur seals. Given the difference between all other Helicobacter sequences ( $<97.5 \%$ identity), it is likely that these sequences may represent a novel species. However, as the 16S rRNA sequence is not sufficient enough to describe a new species (Dewhirst et al. 2000), other studies would be required to isolate and characterize this organism. Nevertheless, its occurrence in these animals is unique and may reflect the potential for more than 1 species to occur within seals.

Of particular interest was the occurrence of several sequences from captive seals which shared a 98 to 98.6\% identity to Helicobacter spp. previously identified from dolphins and whales (namely $H$. cetorum) (Harper et al. 2002). The occurrence of similar species in multiple animal hosts has also been established for several Helicobacter spp. including $H$. cinaedi (Gebhart et al. 1989, Fernandez et al. 2002), H. canis (Stanley et al. 1993, Foley et al. 1999), H. pametensis (Dewhirst et al. 1994), and H. pullorum (Stanley et al. 1994) and reflects the potential for transmission between vertebrate groups (Seymour et al. 1994). Whilst the occurrence of similar species in cetaceans and pinnipeds is, thus, consistent with the ability of other Helicobacter spp. to infect a broad range of terrestrial hosts (Solnick \& Schauer 2001), it is surprising that $H$. cetorum was detected in seals housed in facilities (namely AQWA and UWW) devoid of either dolphins or whales. Therefore, providing that the occurrence of such organisms was not a factor of captivity, it would seem plausible that alternative modes of transmission to the horizontal pathway proposed by Harper et al. (2003a) may also be important in the dissemination of Helicobacter species amongst the marine host.

That alternative modes of transmission may be important in the dissemination of Helicobacter species amongst vertebrate groups has been reported for species such as $H$. canadensis, where geese were reported as a reservoir for its transmission to humans (Walderström et al. 2003). Within the current study, Helicobacter was also detected in a sample containing the feces of several wild silver gulls. Moreover, the sequence obtained from this sample, though substantially different to other species previously identified from birds (namely H. pullorum and H. pametensis) (Dewhirst et al. 1994, Stanley et al. 1994), maintained a $100 \%$ identity to several other sequences obtained from seals from the same location. Considering that other organisms such as Brucella, Campylobacter and Candida may be spread between marine taxa via birds or the ingestion of other marine organisms (Dunn et al. 1984, Broman et al. 2000, Foster et al. 2002), and that seal rookeries are often co-inhabited by various foraging bird species (Silverman \& Veit 2001), it is not surprising that these animals share similar Helicobacter species. However, whether birds act as a vector for the trans- mission of such organisms within the captive setting requires further examination.

Acknowledgements. The authors thank UnderWater World (Mooloolaba), Sea World (Gold Coast), and the Aquarium of Western Australia, (Perth), Australia, and their staff for support and cooperation in the collection of samples. We also thank M. Wos for assistance in the laboratory and B. Page, J. McKenzie and S. Goldsworthy from LaTrobe University (Australia) for their valuable time and assistance in the collection of wild samples. This work was supported by the National Marine Science Centre, Coffs Harbour and the School of Biological, Biomedical and Molecular Sciences of the University of New England, Armidale, Australia. Support was also provided by the Faculty of Science of the University of the Sunshine Coast, Maroochydore D.C., Australia.

\section{LITERATURE CITED}

Al-Soud WA, Bennedsen M, On SL, Ouis IS, Vandamme P, Nilsson HO, Ljungh A, Wadstrom T (2003) Assessment of PCR-DGGE for the identification of diverse Helicobacter species, and application to faecal samples from zoo animals to determine Helicobacter prevalence. J Med Microbiol 52:765-771

Birnbaum N, Barr SC, Center SA, Schermerhorn T, Randolph JF, Simpson KW (1998) Naturally acquired leptospirosis in 36 dogs: serological and clinicopathological features. J Small Anim Pract 39:231-236

Broman T, Bergström S, On SLW, Palmgren H, McCafferty DJ, Sellin M, Olsen B (2000) Isolation and characterization of Campylobacter jejuni subsp. jejuni from Macaroni Penguins (Eudyptes chrysolophus) in the Subantarctic region. Appl Environ Microbiol 66:449-452

Brown LM (2000) Helicobacter pylori: epidemiology and routes of transmission. Epidemiol Rev 22:283-297

Covacci A., Telford JL, Del Giudice G, Parsonnet J, Rappuoli R (1999) Helicobacter pylori virulence and genetic geography. Science 284:1328-33

Cover TL (1997) Commentary: Helicobacter pylori transmission, host factors, and bacterial factors. Gastroenterology 113:S29-S30

Dewhirst FE, Seymour C, Fraser GJ, Paster BJ, Fox JG (1994) Phylogeny of Helicobacter isolates from bird and swine feces and description of Helicobacter pametensis sp. nov. Int J Syst Bacteriol 44:553-560

Dewhirst FE, Fox JG, On SL (2000) Recommended minimal standards for describing new species of the genus Helicobacter. Int J Syst Evol Microbiol 50:2231-2237

Dooley CP, Cohen H, Fitzgibbons PL, Bauer M, Appleman MD, Perez-Perez GI, Blaser MJ (1989) Prevalence of Helicobacter pylori infection and histologic gastritis in asymptomatic persons. N Engl J Med 321:1562-1566

Dunn JL, Buck JD, Spotte S (1984) Candidiasis in captive pinnipeds. J Am Vet Med Assoc 185:1328-1330

Fernandez KR, Hansen LM, Vandamme P, Beaman BL, Solnick JV (2002) Captive rhesus monkeys (Macaca mulatta) are commonly infected with Helicobacter cinaedi. J Clin Microbiol 40:1908-1912

Foley JE, Marks SL, Munson L, Melli A, Dewhirst FE, Yu S, Shen Z, Fox JG (1999) Isolation of Helicobacter canis from a colony of Bengal cats with endemic diarrhea. J Clin Microbiol 37:3271-3275 
Forbes LB (2000) The occurrence and ecology of Trichinella in marine mammals. Vet Parasitol 93:321-334

Foster G, MacMillan AP, Godfroid J, Howie F and 5 others (2002) A review of Brucella sp. infection of sea mammals with particular emphasis on isolates from Scotland. Vet Microbiol 90:563-580

Fowler ME (1996) An overview of wildlife husbandry and diseases in captivity. Rev Sci Tech 15:15-42

Fox JG (2002) The non-H pylori helicobacters: their expanding role in gastrointestinal and systemic diseases. Gut 50: $273-283$

Fox JG, Lee A (1997) The role of Helicobacter species in newly recognized gastrointestinal tract diseases of animals. Lab Anim Sci 47:222-255

Gebhart CJ, Fennell CL, Murtaugh MP, Stamm WE (1989) Campylobacter cinaedi is normal intestinal flora in hamsters. J Clin Microbiol 27:1692-1694

Germani Y, Dauga C, Duval P, Huerre M, Levy M, Pialoux G, Sansonetti P, Grimont PA (1997) Strategy for the detection of Helicobacter species by amplification of 16S rRNA genes and identification of $\mathrm{H}$. felis in a human gastric biopsy. Res Microbiol 148:315-326

Goldman CG, Loureiro JD, Quse V, Corach Dand 6 others (2002) Evidence of Helicobacter sp. in dental plaque of captive dolphins (Tursiops gephyreus). J Wildl Dis 38: 644-648

Hall TA (1999) BioEdit: a user-friendly biological sequence alignment editor and analysis program for Windows 95/98/NT. Nucleic Acids Symp Ser 41:95-98

Harper CG, Feng Y, Xu S, Taylor NS and 7 others (2002) Helicobacter cetorum sp. nov., a urease-positive Helicobacter species isolated from dolphins and whales. J Clin Microbiol 40:4536-4543

Harper CG, Whary MT, Feng Y, Rhinehart HL, Wells RS, Xu S, Taylor NS, Fox JG (2003a) Comparison of diagnostic techniques for Helicobacter cetorum infection in wild Atlantic bottlenose dolphins (Tursiops truncatus). J Clin Microbiol 41:2842-2848

Harper CG, Xu S, Rogers AB, Feng Y and 7 others (2003b) Isolation and characterization of novel Helicobacter spp. from the gastric mucosa of harp seals Phoca groenlandica. Dis Aquat Org 57:1-9

Higgins R (2000) Bacteria and fungi of marine mammals: a review. Can Vet J 41:105-116

Kumar S, Tamura K, Jakobsen IB, Nei M (2001) MEGA2: molecular evolutionary genetics analysis software. Bioinformatics 17:1244-1245

Lauckner G (1985) Diseases of Mammalia: Pinnipedia. In: Kinne O (ed) Diseases of marine animals. Biologische Anstalt Helgoland, Hamburg, p 683-772

Lento GM, Hickson RE, Chambers GK, Penny D (1995) Use of spectral analysis to test hypotheses on the origin of pinnipeds. Mol Biol Evol 12:28-52

Mazzucchelli L, Wilder-Smith CH, Ruchti C, Meyer-Wyss B, Merki HS (1994) Gastrospirillum hominis in asymptomatic, healthy individuals. Dig Dis Sci 38:2087-2089

Editorial responsibility: Murray Dailey,

Sausalito, California, USA
Neiger R, Dieterich C, Burnens A, Waldvogel A, CorthesyTheulaz I, Halter F, Lauterburg B, Schmassmann A (1998) Detection and prevalence of Helicobacter infection in pet cats. J Clin Microbiol 36:634-637

Norris CR, Marks SL, Eaton KA, Torabian SZ, Munn RJ, Solnick JV (1999) Healthy cats are commonly colonized with 'Helicobacter heilmannii' that is associated with minimal gastritis. J Clin Microbiol 37:189-194

Oros J, Rodriguez JL, Patterson-Kane J (1998) Gastric cryptosporidiosis in a wild frilled lizard from Australia. J Wildl Dis 34:807-810

Seymour C, Lewis RG, Kim M, Gagnon DF, Fox JG, Dewhirst FE, Paster BJ (1994) Isolation of Helicobacter strains from wild bird and swine feces. Appl Environ Microbiol 60: $1025-1028$

Silverman ED, Veit RR (2001) Associations among Antarctic seabirds in mixed species feeding flocks. Ibis 143:51-62

Simmons JH, Riley LK, Besch-Williford CL, Franklin CL (2000) Helicobacter mesocricetorum sp. nov., a novel Helicobacter isolated from the feces of Syrian hamsters. J Clin Microbiol 38:1811-1817

Smith AW, Brown RJ, Skilling DE, Bray HL, Keyes MC (1977) Naturally-occurring leptospirosis in northern fur seals (Callorhinus ursinus). J Wildl Dis 13:144-148

Solnick JV, Schauer DB (2001) Emergence of diverse Helicobacter species in the pathogenesis of gastric and enterohepatic diseases. Clin Microbiol Rev 14:59-97

Stackebrandt E, Goebel BM (1994) Taxonomic note: a place for DNA-DNA reassociation and 16S rRNA sequence analysis in the present species definition in bacteriology. Int J Syst Bacteriol 44:864-869

Stanley J, Linton D, Burnens AP, Dewhirst FE, Owen RJ, Porter A, On SL, Costas M (1993) Helicobacter canis sp. nov., a new species from dogs: an integrated study of phenotype and genotype. J Gen Microbiol 139: 2495-2504

Stanley J, Linton D, Burnens AP, Dewhirst FE, On SL, Porter A, Owen RJ, Costas M (1994) Helicobacter pullorum sp. nov.-genotype and phenotype of a new species isolated from poultry and from human patients with gastroenteritis. Microbiology 140:3441-3449

Sweeney JC (1974) Common diseases of pinnipeds. J Am Vet Med Assoc 165:805-810

Thomas F, Verneau O, De Meeus T, Renaud F (1996) Parasites as host [corrected] evolutionary prints: insights into host evolution from parasitological data. Int J Parasitol 26: $677-686$

Thompson JD, Higgins DG, Gibsonn TJ (1994) CLUSTAL W: improving the sensitivity of progressive multiple sequence alignment through sequence weighting, position-specific gap penalties and weight matrix choice. Nucleic Acids Res 22:4673-4680

Walderström J, On SLW, Ottvall R, Hasselquist D, Harrington CS, Olsen B (2003) Avian reservoirs and zoonotic potential of the emerging human pathogen Helicobacter canadensis. Appl Environ Microbiol 69:7523-7526

Submitted: March 15, 2004; Accepted: February 14, 2005

Proofs received from author(s): June 22, 2005 